\title{
THE EFFECTIVENESS OF AUTHORITY IN THE MANAGEMENT OF VILLAGE NATURAL RESOURCE IN TIMOR TENGAH UTARA REGENCY: A CASE STUDY OF NON-METALIC MINERAL AND ROCKS MANAGEMENT IN VILLAGES OF NOEMUTI DISTRICT, TIMOR TENGAH UTARA REGENCY
}

\author{
Ahoinnai Krysogonus*, Djaha Ajis Salim Adang, Sayrani Laurensius $\mathbf{P}$. \\ Master's Program in Administrative Sciences, Postgraduate Program, \\ University of Nusa Cendana Kupang, Indonesia \\ *E-mail: krysogonus@gmail.com
}

\begin{abstract}
This research aimed to describe and explain (1) the effectiveness of authority in the management of natural resources in the villages of Timor Tengah Utara (TTU) Regency; (2) factors influencing the effectiveness of authority in the management of natural resources in the villages of TTU Regency. This research used a qualitative approach and a case study approach. The research site was Noemuti District, TTU Regency, East Nusa Tenggara, Indonesia. This research focused on two primary topics. The first topic is the effectiveness of authority, which is elaborated into (a) goal attainment approach, (b) systems approach, and (c) strategic constituents approach. The second topic is the supporting and inhibiting factors, focusing on factors supporting the effectiveness of authority in managing natural resources. The purposive sampling technique (using specific considerations) was used in selecting informants. We used primary and secondary data. Data was collected through interviews, documentation, and observation. The research results showed that authority in the management of natural resources was not effective, which resulted from the many violations in the management of natural resources. About $37 \%$ of the license application process was ineffective. Also, $40 \%$ of the issuance process of Izin Usaha Pertambangan (IUP) or Exploration Mining Business License was ineffective. Then, 83\% of the Production Operation stage was ineffective. The post-mining stage produced no findings as there were no mining companies engaged in post-mining rehabilitation at the research time. In general, $53 \%$ of natural resource management in TTU Regency villages was ineffective.
\end{abstract}

\section{KEY WORDS}

Effectiveness, authority, management, natural resources, village, mining.

Mining authority revolved around the top-level government; for instance, the central government, the provincial government, and the regency or city government. Mining authority generally refers to the provincial and central governments. Village governments are the lowest level of government. Villages undergo natural resource exploitation, such as mining. However, village governments were not involved in natural resources management. Regardless of the principle of recognition and principle of subsidiary, village governments were overlooked in mining operations. Villages and their community are the main object of natural resource exploitation and are directly affected by natural resource exploitation. Villages lack authority on mining operations, let alone receiving benefits from the mining operation.

Authority may be mandated for villages to increase the effectiveness of authority. Villages may be involved in the control function. In addition, village governments are closer to the mining site and can do the control function easier than the provincial government. Badan Usaha Milik Desa (BUMDES) or Village-Owned Enterprises may be involved and empowered to manage village potential. Villages may obtain a small portion of mining yields for utilization and maintenance purposes. However, mining operation causes environmental damage. As a result, villages suffer from environmental damage. Furthermore, villages possess no authority and capacity to relocate. 
Timor Tengah Utara (TTU) Regency possesses abundant potential in the mining sector. The mining sector is one of the mainstays of the regency. The mining sector yield consists of Tuafan limestone, Lepungan limestone, dolomite limestone, coral limestone, Pasiran limestone, Padam limestone, sandstone, mountain sand, Omamen sandstone, clay, colored stone, quartz or carbonate sand, gneiss, marble, calcite, Diabas, Rijangan limestone, Napal, bentonite, ocher, sand, river sandstone, mountain sandstone, and manganese. These mining yields are found in almost all TTU districts. The mining yields are processed into light bricks, ceramics, fertilizers, cement, soap, paint, toothpaste, brick, lime, ornament, roof tiles, building materials, iron, and steel. The amount of mining resources deposit in TTU is $41,471,552,955 \mathrm{~m}^{3}$. The Group A and B mineral potential are nickel $(2.637$ ppm), copper (223.8 ppm), silver (31.7 PPm), and gold (223.9 ppm). On the other hand, Group C mineral potential is 321.798 .466 tons of marble available in several districts.

Villages in Noemuti District are one of the mining sites in TTU Regency. There are 12 villages in Noemuti District. These villages possess different mining potentials. The following table describes the mining potential in those villages:

Table 1 - Village and Mining Potential Area

\begin{tabular}{rlllr}
\hline No & \multicolumn{1}{c}{ Village } & \multicolumn{1}{c}{ District } & \multicolumn{1}{c}{ Regency } & Mining Potential Area(Ha) \\
\hline 1 & Noebaun & Noemuti & Timor Tengah Utara & 5.46 \\
\hline 2 & Kiuola & Noemuti & Timor Tengah Utara & 105.45 \\
\hline 3 & Bijeli & Noemuti & Timor Tengah Utara & 7.50 \\
\hline 4 & Nifuboke & Noemuti & Timor Tengah Utara & 0.79 \\
\hline 5 & Oenak & Noemuti & Timor Tengah Utara & 47.47 \\
\hline 6 & Kuaken & Noemuti & Timor Tengah Utara & 7.77 \\
\hline 7 & Fatumuti & Noemuti & Timor Tengah Utara & 15.07 \\
\hline 8 & Noemuti & Noemuti & Timor Tengah Utara & 26.69 \\
\hline 9 & Banfanu & Noemuti & Timor Tengah Utara & 5.97 \\
\hline & & & TOTAL & 222.16 \\
\hline
\end{tabular}

Source: Noemuti District Figures, 2018.

Noemuti District possesses a total mining area of 293.63 hectares. Mining operation near the villages of Noemuti District directly affects the environment, community, and ecosystem. However, villages in Noemuti District do not possess the authority to manage mining operations. The villages do not receive benefits from the mining operation and remain an observer. Instead, the upper-level government holds the authority to mining operation management and license issuance. In addition, the upper-level government benefits from the mining operation. Furthermore, the villages do not receive funds for relocation or environmental rehabilitation after the mining operation ceased.

There were issues between the community, the villages, the miners, and the government regarding Mineral C Mining Operation (currently addressed as Non-Metal Minerals and Rocks). A similar issue occurred in Naiola Village, East Noemuti District, TTU Regency. The community intended to conduct Mineral C Mining Operations, in the form of rock and sands, in Noemuti, Naiola, and Oenak Rivers. The community repeatedly submitted license applications to Nusa Tenggara Timur (NTT) Provincial Mining and Energy Office to conduct Mineral $\mathrm{C}$ mining operations in the 10-hectare mining area. However, the requests were never followed up. Therefore, the community accused East Nusa Tenggara Provincial Mining and Energy Office of deliberately complicating mining license applications. The community has repeatedly raised funds to facilitate East Nusa Tenggara Provincial Mining and Energy Office in conducting field tests. However, the community has not obtained a mining license. However, the East Nusa Tenggara Provincial Mining and Energy Office argued that the submission was missing (Victor News, 2019).

Sand mining in Noemuti Village, TTU Regency, caused environmental damage. Leko (2020) observed sand mining in Noemuti, TTU Regency. Leko discovered a dried water source, damaged rice fields, and a hungry community. Sand mining in Noemuti River affected the Tainunus rice fields, Naiola Village, East Noemuti District, and Riber rice fields 
in Oenak Village, South Noemuti District. CV. Christin, CV. Karitas, PT. SKM and PT. Surya Raya Timor mined and extracted sand in the Noemuti River.

After six years of the mining operation, most of the rice fields in Taiunus and Oenak could not be cultivated. Sand mining eroded the surface of the Noemuti River. As a result, the water from the Noemuti River could not flow into the water channel. The community complained about the dried water channel, dried rice fields, and cracked soil in the rice fields. In addition to Taiunus and Oenak, mining operations affected the Klae rice fields in Naiola Village. Before the mining operation, the local community could cultivate the fields more than once annually. However, the provincial government, TTU Regency government, and the village government built supporting infrastructure (gabion and concrete blocks) surrounding the Klae rice fields. The exploitation of the mining companies was dangerously close to the infrastructure and rice fields, so it caused environmental damage to the rice fields. Besides, the community lost access to clean water (Leko NTT, 2020).

On Thursday, July $9^{\text {th }}, 2020$, youth, elders, mothers, and the local community members affected by the mining operation demanded justice. One community group marched towards the mining site of CV. Cristin around the Klae rice fields. The other group visited the TTU Regional People's Representative. The community brought demonstration property to Noemuti River and TTU Regional People's Representative. The community protested and demanded justice.

According to the government perspective, a village is the smallest and lowest form of government. Also, a village is the closest government organization to the community. "Smallest" indicates that the region and governmental task under village government have the smallest scope or size than the city/regency, provincial, and central government organization. "Lowest" indicates that the village has the lowest government structure in the Republic of Indonesia. However, "lowest" does not mean that the village is subordinate to the district/ regency nor the village head is subordinate to the regent/mayor. Article 200 of Law Number 32 of 2004 states that village governments are not under the regency/city government. Law Number 6 of 2014 states that villages are located within the regency/city territory, similar to regency/city within a province. "Lowest" means that village governments are directly related to and integrated with the social, cultural, and economic life of the community. The term "lowest" is similar to "front" and "near". "Front" means that village governments directly relate to community members in governance, service, development, empowerment, and society (Putri, 2016).

Based on the descriptions above, village governments are a lower-level government capable of increasing service effectiveness in their governance area. Village governments' authority and direct supervision may increase the effectiveness of mining operations. Village governments may study village-scale local authority related to the mining operation. The study may enrich village-scale local authorities, delegated authorities, or mandated authorities. Doing so may increase the village governments' effectiveness in managing natural resources.

Therefore, we conducted the present study entitled "The Effectiveness of Authority in the Management of Village Natural Resource in Timor Tengah Utara Regency (A Case Study of Non-Metallic Mineral and rocks Management in Villages of Noemuti District, Timor Tengah Utara Regency)". The study aimed to explain: 1) the effectiveness of authority in the management of natural resources in the villages of Timor Tengah Utara (TTU) Regency; and (2) factors influencing the effectiveness of authority in the management of natural resources in the villages of TTU Regency.

\section{REVIEW OF RELATED LITERATURE}

\section{Effectiveness}

\section{Description of Effectiveness}

According to The Liang Gie in Halim (2004), effectiveness is a condition that occurs due to desire. An individual conducts an action with specific purposes and desires. 
Effectiveness occurs when the action produces a result as intended. Effectiveness is an individual achievement of goals in certain activities.

According to Soedjadi in Prasetyo (2010), effectiveness occurs when activities adhere to a predetermined time. Furthermore, effectiveness indicates that individuals carry out official procedures following a predetermined plan.

Effectiveness is the achievement of predetermined goals or objectives in any organization, activity, or program. Effectiveness occurs when achievement adheres to predetermined goals or objectives. Mahmudi (2005) states that effectiveness is the relationship between output and objectives. The more significant the contribution of output to the goal achievement, the more effective the organization and program or activity is. Kurniawan (2005) defines effectiveness as the ability to carry out tasks, functions (operating program activities or missions) of an organization. Also, there is no pressure or tension in its implementation.

Based on the theories mentioned above, effectiveness is the level of success or failure in achieving predetermined goals. Besides, effectiveness indicates an approach used to determine the success or failure of a predetermined plan. Furthermore, effectiveness is a measure that determines targets or goal achievement.

\section{Factors Influencing Organizational Effectiveness}

According to Mohyi (1999), internal and external factors influence an organization. The factors influencing organizational effectiveness is described as follows:

a. Internal factors.

(1) The organizational structure and technology. This factor influences the appropriateness of organizational structure and the use of technology. The organizational structure and technology influence the organizational objectives, the organization size, the quantity and quality of employees, and the existing facilities.

(2) Human resources quality and behavior. Quality is defined as employee knowledge and skills. Behaviour is defined as employees' perceptions, desires, and actions.

(3) Organizational culture reflects employees' mindset, speech style, and consistent behavior, such as decision-making, communication, and interactions with the internal and external environment.

(4) Management policies and practices. Specific policy improves practice or managerial activities. Furthermore, management policies and practices improve the goal achievement of an organization.

b. External Factors, for instance, external environment behavior. The external environment is related to economic conditions, government policies, politics, socio-culture, customers, and so forth. There are controllable and uncontrollable external factors. Uncontrollable factors have more influence than controllable factors. Uncontrollable factors could deter organizations from making policies and formulating strategies.

Steers in Purnomo (2006) stated that four factors influence organizational effectiveness: organizational characteristics, environmental characteristics, employee characteristics, and management policies or practices. The four factors influencing organizational effectiveness are described as follows:

a. Organizational characteristics are relatively fixed relationships-for instance, the composition of human resources in the organizational structure. In the organizational structure, employees are part of a relatively fixed relationship. Furthermore, employees determine interaction patterns and task-oriented behavior.

b. Environmental characteristics. (1) The external environment refers to the environment outside the organization. The external environment is highly influential to the organization-for instance, decision making and action. (2) The internal environment is the environment within an organization (organizational climate).

c. Employee characteristics are the factor that significantly influences effectiveness. Each individual has differences. Individual awareness of individual differences is crucial to achieving organizational goals. Organizations integrate individual goals and organizational goals to achieve success. 
d. Management characteristics are a strategy and work mechanism designed to coordinate the organization and achieve effectiveness.

\section{Organizational Effectiveness Model}

Robbins (1990), borrowing Kim's opinion, state four approaches to measuring organizational effectiveness:

a) Goal Attainment Approach

The goal attainment approach measures the extent of achieved objectives. The goal attainment approach emphasizes a result instead of a process. The requirements of the goal attainment approach are clear objectives, time limit, and measurability. Siagian (1978) describes the criteria for effective goal achievement as follows :

1. Clarity of goals

2. Clarity of strategy

3. Steady analysis process and policy formulation

4. Careful planning

5. Appropriate program formulation

6. Availability of work facilities and infrastructure

7. Effective and efficient implementation

8. Educational supervision and control system

b) Systems approach

The systems approach measures the availability of resources, nurtures the organization as an organism, and interacts with the external environment successfully. The systems approach requires a clear relationship between input and output.

The term system is widely used. System-related concepts have been applied in various system designs for problem solving and management. A system consists of physical and non-physical components. These components are related to each other and work harmoniously to achieve a particular goal. The basic model of the systems approach is input, processing, and output. The following figure describes the systems approach model:

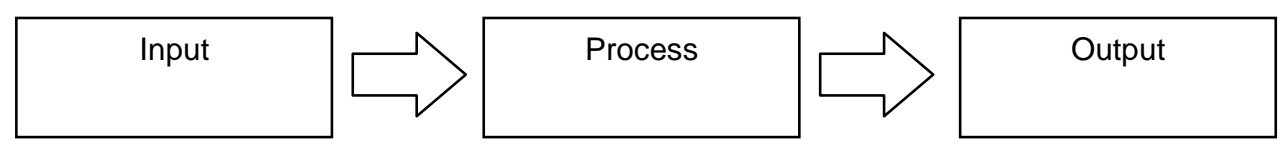

Figure 1 - Basic Concept of the Systems approach (Susanto, 2004)

According to Hardcastle (2011), the purpose of the system is to receive input, process input, and produce output in the form of information. There are five general components of the system: input, process, output, feedback, and control.

A system consists of input, process, and output. Input consists of sources generated into raw materials. The process is a strategy to process raw materials into products. The output is the products or goods that users buy or consume. The outcome is the benefit affecting users or parties outside the system (Hasanbasri, 2007)

c) Strategic Constituencies Approach

The strategic constituencies approach measures the satisfaction level of key constituents. The existence of an organization requires key constituent supports. Assuming that the constituents have a strong influence on the organization, the organization must respond to constituents' demands.

d) Competing Values Approach

The competing values approach measures the prioritized success criteria of an organization. For instance, equality, service, return on investment, market share, new product innovation, and job security. These criteria adhere to the interests or preferences of the constituents. 
There are various approaches to measure organizational effectiveness. However, none of the approaches is perfect. Each approach has distinct advantages over others. Organizational effectiveness may be measured using the goal attainment approach, resource approach, systems approach, strategic constituent approach, and competitive values approach (Gibson et al., 1995).

The systems approach possesses a weakness, as it focuses on the method to achieve effectiveness instead of organizational effectiveness. Systems approach measures process variables. For instance, how the organization interacts and influences the open environment. Therefore, the systems approach lacks a reliable measurement tool to determine quantity or intensity (Robbins, 1994).

The strategic constituent approach measures organizational effectiveness by observing overall activities in an organization. The strategic constituent approach focuses on various components within and outside the organization related to organizational performance-for instance, employees, shareholders, material suppliers, owners, and so on. The strategic constituent approach measures organizational effectiveness through the satisfaction level of each constituent element within an organization (Lubis dan Huseini, 1987). However, the strategic constituent approach has a weakness. The satisfaction level of constituent groups or customer is relative and difficult to measure. Each constituent component has different criteria and interests to assess the organization.

\section{Authority}

\section{Definition of Authority}

In Indonesian, kewenangan (authority) is derived from wenang (right and power of conduct). Kewenangan is defined as an authority, namely the right and power to conduct (Hadjon, 2005). Kewenangan is formal power derived from legislative power (given by law) or from administrative executive power. Kewenangan consists of power over a particular group of people or power over an area of government. (Atmosudirdjo, 1981).

Syafrudin (2000) argues that there is a difference between the meaning of kewenangan and wewenang. There is a difference between kewenangan (authority or gezag) and wewenang (capacity or bevoegheid). Kewenangan is formal power given by law. On the other hand, wewenang concerns a certain "onderdeel" (part) of the authority. Kewenangan possesses various wewenang (rechtsbe voegdheden or legal power). Wewenang is the scope of public legal action, government authority, and authority to make a governmental decision (bestuur). Wewenang is the authority to carry out duties, grant, and distribute authority. These functions are primarily stipulated in the law. Juridically, the definition of wewenang is the ability given by laws and regulations to create legal consequences (Indroharto, 1993).

Based on the various definitions of kewenangan, there is a distinct difference between kewenangan and wewenang. Kewenangan is the formal power derived from law. On the other hand, wewenang is the specification of authority. Therefore, any legal subject mandated with kewenangan possesses wewenang. The aforementioned legal subject has legal power within their authority. Based on the theories mentioned above, the researcher argued that authority is a legal right of an official or institution. The official or institution exercises authority based on the applicable laws and regulations.

\section{Sources of Authority}

Indroharto (1993) argues that authority is obtained through attribution, delegation, and mandate. Attribution means granting new government authority through a law provision. Therefore, creating a new government authority. Delegation is the process of transferring the existing authority from an agency or office (possessing attributive authority) to another agency or office. Therefore, delegation is preceded by an attributive authority. The mandate does not create new authority or delegation of authority from one agency/office to another.

Hadjon in Ridwan (2013) states that government action should adhere to legitimate authority. Authority is obtained through attribution, delegation, and mandate. Attribution is 
outlined through the division of state power through the constitution. Delegation and mandate are authority derived from the commission. Hadjon in Ridwan (2013) makes a distinction between delegation and mandate. Delegation procedure comes from one organ of government to another, adhering to regulations. Therefore, the responsibility and accountability shift to the delegates. The delegator could not peruse the authority. However, the delegator may revoke the authority using the "contrarius actus" principle. It indicates that every change or revocation of regulation is conducted by the official who stipulates the regulation. The change or revocation is conducted using the regulation of a similar or higher level. The mandate is the context of a routine supervisory subordinate relationship. The responsibility and accountability remain with the mandate. At any time, the mandator may use its authority.

\section{Village and Village Authority}

According to Law Number 6 of 2014, villages (villages and traditional villages or what are referred to by other names) are legal community units possessing territorial boundaries. Villages are authorized to regulate and administer government affairs, local communities' interests based on community initiatives, rights of origin, and/or traditional rights recognized and respected by the Republic of Indonesia. According to Solekhan (2014), a legal community unit has the authority to regulate and manage its interests. Therefore, the village has autonomy limited to the rights of origin and local customs. Furthermore, village autonomy has existed for a long time and is inherent in the village community.

Based on the definition above, there are three critical elements related to village regulation and management authority. The first is authority adhering to the initiative of the local community. The second is authority adhering to the right of origin or customs of the local community. The third is the recognition and appreciation of the state/government on the village authority. Community initiatives adhere to the needs/interests of the local community. Community needs/interest develop adhering to current development. The rights of origin and customs are the product of past community initiatives. These initiatives were useful and continue to be maintained.

According to Tarigan and Mustaya in Eko and Rozaki (2005), village authority focuses on managing natural and economic resources for the community welfare. Village authority distributes resources to all groups, including marginalized groups. Law Number 22 of 1999 amended by Law Number 32 of 2004, further amended by Law Number 23 of 2014 granted three central powers of villages, namely: (1) authority adhering to the village rights of origin; (2) authority adhering to prevailing Law not exercised by the regional and central government; and (3) assistance from the government, provincial government, and/or district governments to villages. This assistance consists of financing, facilities and infrastructure, and human resources (Eko and Rozaki, 2005).

Eko and Rozaki (2005) identify four types of village authority. (1) Generic authority or original authority refers to the right or authority of origin inherent in the village as a legal community unit. Generic authority is known as the community's property right to regulate and manage households (Eko and Rozaki, 2005). Generic authority is often referred to as a form of genuine autonomy. (2) Devolution authority is authority attached to the village due to its position as a local government (local-self government), although a village is not recognized as an autonomous entity such as a regency/city. Villages, as a form of local government (local-self government), have a village government (executive) and a Badan Perwakilan Desa (BPD) or Village Representative Body as a legislative device. BPD has the authority to make village regulations(Eko and Rozaki, 2005) (3) Distributive authority is the authority to manage government affairs (fields), which are divided (instead of delegations) by the government to the village. Law Number 22 of 1999, amended by Law Number 32 of 2004, further amended by Law Number 23 of 2014, state that distributive authority is referred to as "the authority of prevailing law officers not exercised by the regional and central government". In practice, distributive authority is often criticized as "kewenangan kering" or "dry authority" due to its unclear nature. Furthermore, distributive authority is referred to as "kewenangan sisa" or "residual authority" as villages receive unclear residual authority 
(because regency/city has taken the authority) from the supra desa ${ }^{1}$ (Eko and Rozaki, 2005); (4) Authority in implementing empowerment tasks. In reality, villages have no authority to implement empowerment tasks due to their nature. Empowerment tasks consist of financing, facilities and infrastructure, and human resources. Besides, empowerment task requires implementation report and accountability (Eko and Rozaki, 2005).

\section{METHODS OF RESEARCH}

This research used a qualitative design and case study research. The research site was Noemuti District, TTU Regency, Indonesia. This research focused on two aspects. (1) The first is the effectiveness of authority in managing non-metallic minerals and rocks in Noemuti District, TTU Regency. Furthermore, the effectiveness of authority was further elaborated into several aspects. (a) The goal attainment approach compared the objectives and the reality of non-metallic minerals and rocks management. (b) The systems approach measured input effectiveness, process effectiveness, effectiveness, outputs, and outcome effectiveness. (c) The strategic constituent approach measured the satisfaction level of the key constituents. (2) The second is the supporting factors and inhibiting factors of non-metal minerals and rocks management in Noemuti District, TTU Regency. We determined the informants through a purposive technique (using specific considerations). Data sources were primary data and secondary data. Data was collected through interviews, documentation, and observation. The data analysis used Miles and Huberman (2007), namely data reduction, data presentation, and conclusion-drawing or verification. The research result was validated using triangulation techniques.

\section{RESULTS AND DISCUSSION}

The research focused on the effectiveness of authority of non-metallic minerals and rocks management (hereafter referred to as mining operation) in Noemuti District, TTU Regency. Mining is a part or all of the activities in the framework of research, management, and exploitation of minerals or coal. The activities stages were general investigation, exploration, feasibility study, construction, mining, processing and refining, transportation and sales, and post-mining rehabilitation. This research observed mineral (non-metal) and rock mining operations. Mineral mining involves collecting minerals in the form of ore or rock, other than geothermal, oil and gas, and groundwater.

Every individual, group, or organization conducting mining operations for commercial purposes must own mining business. The mining business is an activity within the framework of mineral or coal exploitation. The mining operation involves general investigation, exploration, feasibility study, construction, mining, processing and refining, transportation and sales, and post-mining rehabilitation.

Individual or groups intending to operate a mining business require an Ijin Usaha Pertambangan (IUP) or Mining Business License. IUP is a license to carry out the mining business. There are two types of IUP, namely Exploration IUP and Production Operation IUP. Exploration IUP is a business license to conduct a general investigation, exploration, and feasibility study. Production Operation IUP is a business license issued after the completion of Exploration IUP. Production Operation IUP allows production and operation stage.

There are several activities carried out at the exploration and production stage. At the exploration stage, the company or individual conducts a general investigation, exploration, and feasibility studies in the issued IUP area.

General investigation determines regional geological conditions and indications of mineralization. Exploration determines detailed and accurate information about location, shape, dimensions, distribution, quality, and measurable resources of minerals, social and

\footnotetext{
${ }^{1}$ Supra desa is an individual possessing authority to manage village development.
} 
natural environment. The feasibility study determines a mining business's economic and technical feasibility, analysis of environmental impacts, and post-mining plan.

Production Operations consist of construction, mining, processing, refining, transportation, and sales. Besides, production operations consider controlling environmental impacts adhering to the result of the feasibility study.

Construction involves building all production operation facilities and controlling environmental impacts. Mining produces minerals and/or coal and associated minerals. Processing and refining improve the quality of minerals and/or coal. Also, processing and refining utilize and obtain associated minerals. Transportation move minerals and/or coal from the mining area and/or processing and refining places to the place of delivery. Sales involve selling mineral or coal mining products.

Analisis Mengenai Dampak Lingkungan (AMDAL) or Environmental Impact Analysis is necessary before the issuance of Exploration IUP or Production Operation IUP. AMDAL studies the major and significant impacts of a planned business and/or activity on the environment. AMDAL is necessary for the decision-making process regarding the conduct of a business and/or activity.

Reclamation is a necessary activity during a mining operation. Reclamation is an activity carried out throughout the mining operation. Furthermore, reclamation manages, restores, and improves the ecosystem and environment quality. Reclamation ensures that the ecosystem and environment may function after mining operation.

After the IUP period expires and mining operations are terminated, every company/individual need to carry out post-mining rehabilitation. Post-mining rehabilitation is a planned and systematic activity that continues after the end of the mining operation. Furthermore, post-mining rehabilitation restores the natural environment and social functions adhering to local conditions in the mining site.

Based on research findings of mining operation in Noemuti Subdistrict, TTU Regency, management process involved license application up to post-mining rehabilitation. License issuance to post-mining rehabilitation consists of various stages, which are described in the figure 2.

Figure 2 shows the mining operation in Noemuti District TTU Regency. There are four main mining operation stages: license application, issuance of exploration IUP, issuance of Production Operations IUP, and post-mining.

There were several activities at each stage. Based on the research result, the activity marked red indicated existing issues. The current issues illustrate the ineffectiveness of mining operations in Noemuti District, TTU Regency.

We used several approaches to measure the effectiveness of authority in mining operations in Noemuti District, TTU Regency.

\section{The Goal Attainment Approach}

The goal attainment approach compares the objective and reality of mining operations. According to Law Number 4 of 2009, minerals and coal are non-renewable natural resources. Therefore, mineral and coal mining is a national asset controlled by the state for community welfare. The objectives of the state management of mineral and coal are:

1. Ensure the effectiveness of mining operations' implementation and control in an efficient, effective, and competitive manner.

2. Ensure the benefits of mineral and coal mining in a sustainable and environmentally friendly manner.

3. Ensuring the availability of minerals and coal as raw materials and/or as energy sources for domestic needs.

4. Support and develop national capabilities to encourage competition at the national, regional, and international levels.

5. Increase the income of local, regional, and state communities, and create jobs for the community welfare.

6. Guarantee legal certainty in the implementation of mineral and coal mining operations. 
Eurasia: Economics \& Business, 2(44), February 2021

DOI https://doi.org/10.18551/econeurasia.2021-02

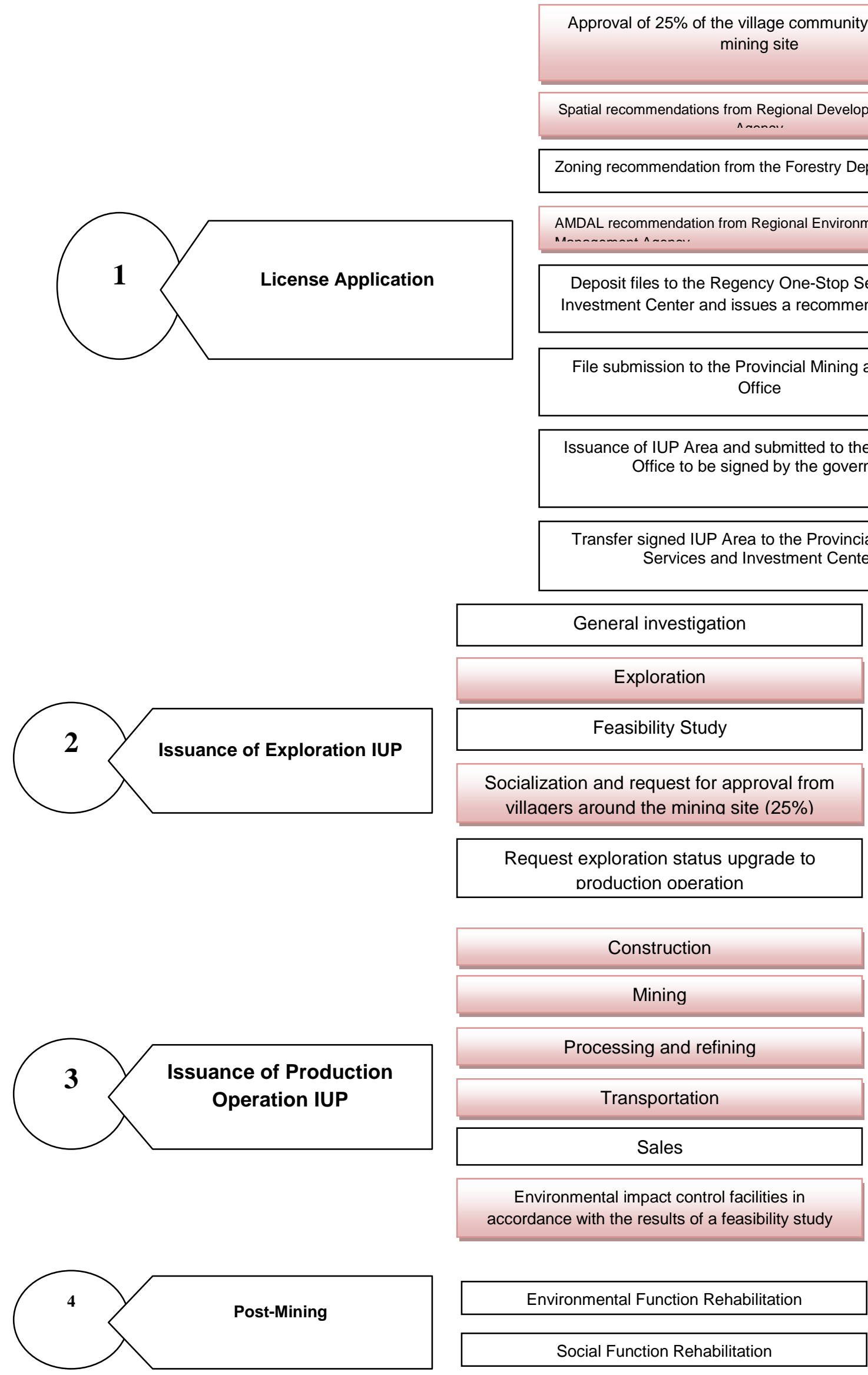

Figure 2 - Mining Operation Stages 
Based on the research result, there were several unrealized objectives. The item "ensure the effectiveness of mining operations' implementation and control in an efficient, effective, and competitive manner" was not realized. There was weak and non-optimal mining operation supervision and control in Noemuti District, TTU Regency. Related Regional Officer Organizations waited and transferred authority to each other. Therefore, supervision and control were non-optimal.

Based on the research result, the item "ensure the benefits of mineral and coal mining in a sustainable and environmentally friendly manner" was non-optimal. There was no reclamation effort on the former mining sites. Furthermore, unauthorized companies made no effort to conduct reclamation efforts. Therefore, the principle of sustainability in a mining operation was unrealized.

Based on the research result, the item "increase the income of local, regional, and state communities, and create jobs for the community welfare" was non-optimal. In this case, the local community in Noemuti District did not benefit from the mining operation. The local communities received a negative impact from the mining operation. Furthermore, there is sizeable regional revenue leakage from the mining operation. Despite the high rate of occurrence, the regional government has not addressed the issue seriously. In addition, the state revenue is prone to leakage due to the absence of supervision and documentation. There is a lack of supervision and documentation on company reports regarding mining volume within a predetermined period.

The item "guarantee legal certainty in the implementation of mineral and coal mining operations" was non-optimal. Based on the research result, the mining companies committed license violations. Besides, there were non-compliance of mining operation obligations-for instance, reclamation and mining techniques. Furthermore, the existence of unlicensed mining companies created injustice towards licensed mining companies.

Law Number 4 of 2009 describes the objectives of Mineral and Coal Mining management. Based on the research result, several of the management objectives were non-optimal. There were $66 \%$ unrealized objectives of mineral and rock mining management. Furthermore, there were 34\% realized objectives of mineral and rock mining management. The figures indicate that there was authority ineffectiveness of mining operation in Noemuti District, TTU Regency.

\section{The Systems approach}

The systems approach measures input effectiveness, process effectiveness, effectiveness, output, and outcome effectiveness. Based on the research result, there were issues on input effectiveness of mining operation in Noemuti District TTU Regency. The issues indicated ineffective input effectiveness. During the IUP application process, some practices harmed the village community participation in the village community approval stage and socialization stage.

Furthermore, research results showed several problems during process effectiveness assessment. The research result found ineffective process effectiveness. License violations occurred and were deliberately overlooked. The lack of serious reclamation effort renders the process effectiveness ineffective.

There was ineffective output effectiveness. There was regional and state revenue leakage. Regional revenue leakage occurred due to non-optimal levies and tax collection on mining operations. Also, there were several violations. State revenue leakage occurred due to discrepancies between company reports and reality. Inadequate monitoring methods encouraged further violations.

Based on the research result, the outcome was ineffective. The mining operation did not benefit the village. Instead, the villages suffered from environmental damage due to a lack of post-mining rehabilitation effort.

\section{The Strategic Constituent Approach}

The strategic constituent approach measured the level of satisfaction of the key constituents. The constituents were village communities, entrepreneurs, regional 
government, the provincial government, and central government. Based on research results using the strategic constituent approach, there was an ineffective mining operation in Noemuti District, TTU Regency.

There was a low constituent level of satisfaction. For instance, the village had a low level of satisfaction. The villages did not benefit from the mining operation. Instead, the village suffered damage to the natural and village environment. Entrepreneurs had a low level of satisfaction due to injustice between licensed mining companies and unlicensed mining companies. The unlicensed mining companies were deliberately overlooked and exempt from sanctions. The regional government had a low level of satisfaction due to regional revenue leakage. Also, the regional government possessed limited authority. Furthermore, the lousy implementation and coordination between horizontal and vertical agencies rendered the Mining Operation in Noemuti District TTU Regency ineffective.

Based on the approaches above, the following figure describes the percentage of ineffectiveness:

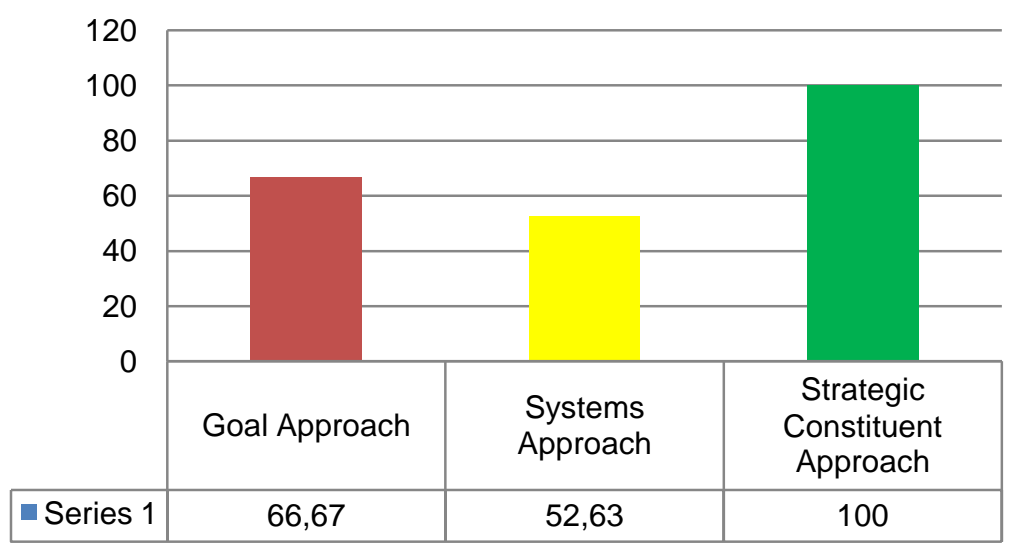

Figure 3 - Percentage of Ineffective Mining Management (Source: Analyzed research results)

Based on the diagram above, the strategic constituent approach showed the highest level of ineffectiveness. All constituents (entrepreneurs, village governments, district governments, and provincial governments) had a low satisfaction level. The goal attainment approach had four unrealized mining objectives and two realized mining objectives. The condition indicated a high level of ineffectiveness. The systems approach determined the level of effectiveness based on each management stage (from the license application stage to the production operation stage).

\section{Internal and External Factors of Mining Operation in Noemuti District, TTU Regency}

Several factors influence the effectiveness of authority on Mining Operation in Noemuti District, TTU Regency. These factors consisted of internal factors and external factors. The internal factors were: (1) organizational structure, (2) human resources quality and behavior, (3) organizational culture, and (4) management policies and practices. On the other hand, the external factors were: (1) economic condition, (2) government policy, (3) political climate, (4) socio-cultural conditions, and (5) customer conditions. The internal and external factors influence the effectiveness of authority of mining operations.

The review of related literature described various internal and external factors. We compared the literature and research findings. Afterward, we listed the relevant supporting and inhibiting factors influencing the effectiveness of authority of mining operation in Noemuti District, TTU Regency.

There were several problems related to the organizational structure. Therefore, organizational culture was categorized as the inhibiting factor. The existing problem in organizational problem was the lack of personnel and lack of authorized personnel to solve an existing problem. 
Eurasia: Economics \& Business, 2(44), February 2021

DOI https://doi.org/10.18551/econeurasia.2021-02

Table 2 - Internal and external factors influencing the authority effectiveness of mining operation in the TTU Regency

\begin{tabular}{clccc}
\hline No & \multicolumn{1}{c}{ Internal Factor } & Research Result & Supporting Factor & Inhibiting Factor \\
\hline 1 & Organization structure & $\sqrt{ }$ & - & $\sqrt{ }$ \\
\hline 2 & Human resources quality and behavior & $\sqrt{ }$ & - & $\sqrt{ }$ \\
\hline 3 & Organizational culture & $\sqrt{ }$ & - & $\sqrt{ }$ \\
\hline 4 & Management practices and policy & $\sqrt{ }$ & - & $\sqrt{ }$ \\
\hline No & External Factor & Research Result & Supporting Factor & Inhibiting Factor \\
\hline 1 & Economic condition & $\sqrt{ }$ & - & $\sqrt{ }$ \\
\hline 2 & Government policy & $\sqrt{ }$ & - & $\sqrt{ }$ \\
\hline 3 & Political climate & $\sqrt{ }$ & - & - \\
\hline 4 & Socio-cultural conditions & $\sqrt{ }$ & $\sqrt{ }$ & - \\
\hline 5 & Customer conditions & $\sqrt{ }$ & $\sqrt{ }$ & \\
\hline
\end{tabular}

Source: Processed research result.

There are several problems related to human resources quality and behavior. Therefore, human resources quality and behavior were categorized into the inhibiting factor. The existing problem was the lack of qualified personnel, the lack of existing personnel assertiveness, the lack of courage in decision making, and weak enforcement of integrity.

The organizational culture had several issues. Therefore, organizational culture was categorized as the inhibiting factor. Organisasi Perangkat Desa (OPD) or Village Officer Organization deliberately overlooks violations. Therefore, the violations were a common occurrence and continued to increase.

Management policy and practices had several issues. Therefore, management policy and practices were categorized as the inhibiting factor. There was a lack of strictly controlled management policies. Also, there were no sanctions on mining companies committing violations. Furthermore, there was a lack of coordination between OPDs, the village government, the provincial government, and the central government. The lack of coordination was due to a lack of financing. OPDs did not receive funds for coordination projects and did not initiate coordination projects.

In addition to internal factors, there were external supporting and inhibiting factors. There were several problems related to economic conditions. Therefore, the economic condition was categorized as the inhibiting factor. Mining operations did not provide economic benefit to the surrounding village community and government. Therefore, the village community tended to be apathetic in monitoring and reporting violations. The village community and elements became vulnerable due to economic factors. The village community could not overcome the mining companies' economic advantage. Therefore, the village community deliberately overlooked mining violations.

Based on the research result, there were several problems related to government policy. Therefore, government policies were categorized as the inhibiting factor. The village government, regency government, and provincial government deliberately overlooked violations and revenue leakage. Policies referred to government conducts. Therefore, overlooking violations were the result of the government policies.

Furthermore, there were several problems related to the political climate. Therefore, the political climate was categorized as the inhibiting factor. The political climate was related to government policy-making and decision-making. Regional heads and other leaders made no decisive actions to optimize and control mining operations. The lack of decisive actions encouraged violations in mining operations. As a result, the mining operations in Noemuti District, TTU Regency were non-optimal and ineffective.

The socio-cultural factor was categorized as the supporting factor. Several villages maintained their social and cultural integrity. These villages rejected mining operations using heavy equipment. Several villages consistently rejected mining operations due to community livelihood and agricultural lands. In addition, several villages conducted mining operations to increase economic income. Those villages rejected mining operations using heavy equipment due to environmental and natural sustainability factors. 
Based on the research result, the customer condition was categorized as the supporting factor. There was a high demand for building materials. The customer demand for building materials increased mining productivity. Therefore, mining operations fulfilled the customer needs in TTU Regency. Furthermore, mining operations in Noemuti District supply other districts in TTU Regency with building materials.

\section{CONCLUSION}

Based on the research result, the conclusions are described as follows:

1. There was authority ineffectiveness in the management of natural resources in TTU regency. There were ineffective management stages and several violations in the detailed stages. There was $37 \%$ ineffectiveness in the license application process. Furthermore, there was $40 \%$ ineffectiveness in the Exploration IUP issuance stage. There was ineffectiveness in the detailed stage of Exploration IUP issuance. There was $83 \%$ ineffectiveness in the Production Operation IUP issuance stage. The detailed stages of the Production Operation IUP issuance stage exhibited ineffectiveness. However, there were no findings during the post-mining stage. No mining companies were conducting post-mining rehabilitation during the time of research. In general, there was 53\% ineffectiveness of natural resources management in TTU Regency.

2. Internal factors and external factors became the supporting and inhibiting factors of natural resources management in TTU Regency. The internal inhibiting factors were: (1) organizational structure, (2) human resources quality and behavior, (3) organizational culture, and (4) management policies and practices. The external inhibiting factors were: (1) economic condition, (2) government policy, and (3) political climate (external factors). Furthermore, the supporting factors were: (1) socio-cultural conditions and (2) customer conditions.

3. There was authority ineffectiveness in the management of natural resources in TTU Regency. The strategic constituency approach showed the highest level of ineffectiveness. Each constituent (entrepreneurs, the village government, the regency government, and the provincial government) showed a low satisfaction level. The goal attainment approach showed four unrealized objectives and two realized objectives of mining operation management. Therefore, the goal attainment approach showed a high level of ineffectiveness. The systems approach showed a high level of ineffectiveness. There were problems related to each management stage (the license application stage to the production operation stage).

Based on research findings, discussion, and conclusions, the following suggestions are presented:

1. Implementing officers in the field requires the courage to take action against various parties who violate regulations. In addition, the officers require adequate intellectual ability. Structural constraints weaken prosecution in the field. Therefore, it is necessary to improve the structural factors.

2. Monitoring various irregularities require good coordination between the provincial and regency government. As the authority in accordance with the law, the provincial government needs to delegate or conduct empowerment tasks to the regency government to improve monitoring effectiveness.

\section{REFERENCES}

1. Atmosudirdjo, P. (1981). Hukum Administrasi Negara. Jakarta: Ghalia Indonesia, Jakarta.

2. Arikunto, S. (2005). Prosedur Penelitian Suatu Pendekatan Praktik. Jakarta: Rineka Cipta.

3. Badan Pusat Statistik Kabupaten Timor Tengah Utara. Kecataman Noemuti Dalam Angka Tahun 2018. 
4. Eko, S., \& Rozaki, A. (2005). Prakarsa Desentralisasi Otonomi Desa. Yogyakarta: IRE Press.

5. Gibson, I. D. (1995). Pre-project planning process for capital facilities, Journal of Construction Engineering and Management ASCE, 121(3), 312-318.

6. Hadjon, P. M. (2005). Pengantar Hukum Administrasi Indonesia. Yogyakarta: Gadjah Mada University Press.

7. Halim, A. (2004). Akuntansi Keuangan Daerah. Jakarta: Salemba Empat.

8. Hardcastle, D. A., Powers, P. R., \&Wenocur, S. (2011). Community Practice: Theories and Skills for Social Workers (3rd Ed). New York: Oxford University Press.

9. Hasanbasri, M. (2007). Pendekatan Sistem dalam Perencanaan Program Daerah. Jurnal Manajemen Pelayanan Kesehatan, 10(02), 56-63.

10. Indroharto. (1993). Usaha Memahami Undang-undang tentang Peradilan Tata Usaha Negara. Jakarta: Pustaka Harapan.

11. Kurniawan, H., \& Alimudin, A. (2015). Pengaruh Kepuasan Kerja, Motivasi Kerja dan Kedisiplinan Terhadap Kinerja Karyawan PT. Garam (PERSERO). Jurnal Magister Manajemen Universitas Narotama,1(2).

12. Lubis, S., Hari, M., \& Hiseini, M. (1987). Teori Organisasi: Suatu Pendekatan Makro. Jakarta: Pusat Antar Universitas IImu-IImu Sosial.

13. Mahmudi. (2005). Manajemen Kinerja Sektor Publik. Yogyakarta: UPP AMP YKPN.

14. Miles, M. B., \& Amichael, H. (2007). Analisis Data Kualitatif Buku Sumber tentang Metode-Metode Baru. Translated by Tjetjep, R. R. Jakarta: Universitas Indonesia.

15. Mohyi. (1999). Teori dan Perilaku Organisasi. Malang: UMM Press.

16. Prasetyo, T. (2010). Kriminalisasi dalam Hukum Pidana. Bandung: Nusa Media.

17. Purnomo, A. (2006). Pengembangan Usaha Kesehatan Sekolah. Jakarta: Departemen Kesehatan.

18. Putri, L. S. (2016). Kewenangan Desa Dan Penetapan Peraturan Desa. Jurnal Legislasi Indonesia, 13(02), $161-176$.

19. Ridwan, H. R. (2013). Hukum Administrasi Negara. Jakarta: PT Raja Grafindo Persada.

20. Robbins, S. (1990). Perilaku Organisasi. Jakarta: Prehalindo.

21. Robbins, S. (1994). Teori Organisasi Struktur Design dan Aplikasi. Jakarta: Arcan, Jakarta.

22. Siagian, S.P. (1978). Manajemen. Yogyakarta: Liberty.

23. Solekhan, M. (2014). Penyelenggaraan Pemerintahan Desa. Malang: Setara Press.

24. Susanto, A. (2004). Sistem Informasi Manajemen. Bandung: Linggar Jaya.

25. Syafrudin, A. (2000). Menuju Penyelenggaraan Pemerintahan Negara yang Bersih dan Bertanggung Jawab. Jurnal Pro Justisia, IV.

26. Undang-Undang Republik Indonesia Nomor 4 Tahun 2009 Tentang Pertambangan Mineral Dan Batubara.

27. Undang-Undang Republik Indonesia Nomor 32 Tahun 2004 Tentang Pemerintahan Daerah.

28. Undang-Undang Republik Indonesia Nomor 6 Tahun 2014 Tentang Desa. 